\title{
PENGEMBANGAN KEWIRAUSAHAAN MELALUI PENINGKATAN KINERJA KARYAWAN
}

\author{
Sukirman \\ Fakultas Ekonomi, Universitas Muria Kudus \\ skirman101@yahoo.com
}

\begin{abstract}
This study aimed to analyze the impact of the employee's performance towards the development of entrepreneurship. This study of employee performance involved variables of creativity, innovation and motivation. It analyzed the impact of creativity, innovation and motivation towards employee performance; it also analyzed the impact of creativity, innovation and motivation for the development of entrepreneurship and analyzed the impact of employee performance towards the development of entrepreneurship. The study focused on 'Jenang Kudus'small scale businesses in Kudus Regency that covered 396 firms (Department of Industry and Trade, Kudus Regency, 2010) and focused on the small scale businesses under the auspices of the Department of Industry and Trade. The population in this study were all 'Jenang Kudus' Small Scale Business companies in Kudus Regency. The sample consisted of 86 companies. The purposive sample technique was used by selecting samples of the small scale businesses in Kudus Regency. Data were collected by using questionnaires and in-depth interviews and they were analyzed by using descriptive method. Employee performance was affected by the creativity, innovation, and motivation. Creativity had a significant and strong direct impact to the employee performance that could create improved performance for employees. Innovation also had a significant and strong direct impact towards employee performance; it is the yardstick in carrying out the day-to-day development of the company so that innovation was needed to improve the performance of employees in the interest of the company. Motivation didn't have any strong and significant impact towards employee performance, it means that motivation is needed to create the performance of employees, so that employees will feel more comfortable and secure in carrying out their job. Both creativity and innovation had strong and significant impact towards the development of entrepreneurship, and on the other hand, motivation had no strong and significant impact towards the development of entrepreneurship.
\end{abstract}

Keywords: Creativity, Innovation, Motivation, Employee Performance, Entrepreneurship.

\section{PENDAHULUAN}

Usaha Mikro, Kecil dan Menengah (UMKM) merupakan kegiatan usaha yang mampu memperluas lapangan kerja dan memberikan pelayanan ekonomi secara luas kepada masyarakat dan dapat berperan dalam proses pemerataan dan peningkatan 
pendapatan masyarakat, mendorong pertumbuhan ekonomi dan berperan dalam mewujudkan stabilitas nasional. Selain itu, UMKM adalah salah satu pilar utama ekonomi nasional yang harus memperoleh kesempatan utama, dukungan, perlindungan dan pengembangan seluas-luasnya sebagai wujud keberpihakan yang tegas kepada kelompok usaha ekonomi rakyat, tanpa mengabaikan peranan Usaha Besar dan Badan Usaha Milik Negara (UU No.20 Tahun 2008).

Pemerintah memberikan perhatian terhadap UMKM karena UMKM memiliki peranan dalam perekonomian nasional. Peran UMKM di Indonesia sangat besar dan telah terbukti menyelamatkan perekonomian bangsa pada saat krisis ekonomi tahun 1997. Scarborough dan Zimmerer (2005) menyatakan bahwa pemulihan krisis ekonomi berjalan selama tujuh tahun dan beberapa studi telah menunjukkan bahwa ekonomi Indonesia tidak hanya mengandalkan peranan usaha besar, tetapi UMKM terbukti mempunyai ketahanan relatif lebih baik dibandingkan dengan usaha skala besar pada masa krisis dan masa pemulihan perekonomian Indonesia saat ini. UMKM memiliki peranan yang sangat strategis dan penting ditinjau dari berbagai aspek (Kuncoro 2006). Pertama, jumlah industrinya yang besar dan terdapat dalam setiap sektor ekonomi. Kedua, potensinya yang besar dalam menciptakan lebih banyak kesempatan kerja bila dibandingkan dengan investasi yang sama pada usaha dengan skala lebih besar. Ketiga, kontribusi UMKM dalam pembentukan Produk Domestik Bruto (PDB) cukup signifikan. Keempat, memiliki sumbangan kepada devisa negara dengan nilai ekspor yang cukup stabil.

UMKM khususnya dalam bidang produksi jenang kudus di kabupaten Kudus merupakan salah satu jenis usaha yang masih mampu bertahan hidup sampai dengan sekarang. Jenang adalah sebuah makanan tradisional dari Kota Kudus, merupakan salah satu produk UKM yang tumbuh melesat cepat diantara produk-produk olahan UKM yang lain. Jenang Kudus telah melewati beberapa titian sejarah yang teramat panjang, bukti perjuangan dan buah dari kegigihan, keuletan dan dikenal sebagai produksi kisah sukses anak bangsa. Pada awal kelahirannya, jenang Kudus merupakan makanan ringan yang belum diperdagangkan. Sejak tahun 1905 pertumbuhan produksi jenang kudus mulai menunjukkan kegairahan sampai dengan sekarang.

Berdasarkan data dari Dinas perindustrian dan perdagangan Kabupaten Kudus menunjukkan bahwa terjadi pertumbuhan pesat jumlah usaha kecil yang melakukan kegiatan industri dalam bidang pengolahan jenang kudus. Pertumbuhan tersebut ditunjukkan dengan adanya peningkatan jumlah pelaku usaha kecil yang memproduksi jenang Kudus seperti tampak pada Tabel 1 berikut. 
Tabel 1

Pertumbuhan Industri Kecil Jenang kudus

\begin{tabular}{clccc}
\hline NO & KECAMATAN & 2008 & 2009 & 2010 \\
\hline 1 & Undaan & 20 & 25 & 43 \\
2 & Kota & 28 & 33 & 36 \\
3 & Gebog & 5 & 9 & 12 \\
4 & Bae & 54 & 61 & 64 \\
5 & Dawe & 7 & 10 & 13 \\
6 & Jekulo & 23 & 35 & 42 \\
7 & Jati & 68 & 75 & 87 \\
8 & Mejobo & 30 & 39 & 43 \\
9 & Kaliwungu & 48 & 53 & 56 \\
\hline & Total & 283 & 340 & 396
\end{tabular}

Sumber: Dinas Perindustrian dan Perdagangan Kabupaten Kudus, diolah, 2010

Perkembangan jumlah usaha kecil jenang Kudus periode 2008-2010 mengalami peningkatan sebesar 39,9 persen yaitu dari 283 perusahaan pada tahun 2008 menjadi 396 perusahaan pada tahun 2010. Pertumbuhan ini sangat dramatis karena dimungkinkan semakin sulitnya mencari pekerjaan sehingga menimbulkan munculnya usaha-usaha baru khususnya dalam industri jenang kudus (Kudus Dalam Angka 2010).

Upaya pemerintah daerah dalam mempertahankan pertumbuhan usaha kecil (UK) jenang Kudus telah menghasilkan dua program strategis, yakni program kewirausahaan dan program kemitraan. Program kewirausahaan akan menjadi basis dalam pengembangan sumber daya manusia. Program ini dipandang penting dan strategis karena sumber daya manusia adalah elemen dasar yang menjadi subyek pembangunan. Dalam pembangunan ekonomi, kewirausahaan menjadi faktor utama dan penting yang selama ini agak terlupakan. Kewirausahaan merupakan karakteristik kemanusiaan yang berfungsi besar dalam mengelola suatu bisnis, karena pengusaha yang memiliki jiwa kewirausahaan akan memperlihatkan sifat pembaharu yang kreatif, dinamis, inovatif dan adaptif terhadap perubahan kemajuan ilmu pengetahuan dan teknologi, dengan kewirausahaan yang tinggi maka manajemen akan dapat diperbaiki secara terus menerus (Suharto 2010:5). Pada dasarnya semua karyawan adalah malas, sehingga harus diawasi dan dimotivasi oleh ketakutan akan hukuman dan mencoba sebanyak mungkin untuk mengelak dari tanggung jawab (Mc. Gregor dalam Timpe 1999). Keuntungan terbesar bagi perusahaan kecil adalah bila para karyawan mempunyai kepandaian umum yang mengetahui seluruh kegiatan perusahaan, selain itu kreativitas dapat dicapai melalui pemikir internal yang diberi tanggung jawab masa depan pekerjaan tersebut (Studer dalam Timpe 1999:53). Komponen yang ada dalam perusahaan dimaksimalkan untuk mencapai tujuan, terutama karyawan untuk dapat meningkatkan kinerjanya melalui motivasi, inovasi dan kreativitas. Pengembangan kewirausahaan yang dinamis membutuhkan karyawan 
yang kompeten dalam bidangnya. Kinerja karyawan yang produktif sangat dibutuhkan perusahaan dalam mendukung pengembangan kewirausahaan karyawan. Kompetensi yang perlu dikembangkan dalam pengembangan kewirusahaan adalah kompetensi kreativitas, inovasi dan motivasi. Berdasarkan uraian latar belakang diatas, maka penelitian ini dilakukan untuk menjelaskan pengaruh kreativitas, inovasi dan motivasi terhadap pengembangan kewirausahaan melalui kinerja karyawan.

Pertanyaan yang dijawab dalam penelitian ini adalah: pertama, bagaimana pengaruh kreativitas, inovasi dan motivasi terhadapkinerja karyawan?Kedua, bagaimana pengaruh kreativitas, inovasi dan motivasi terhadap pengembangan kewirausahaan?Ketiga,bagaimana pengaruh kinerja karyawan terhadap pengembangan kewirausahaan?

\section{KERANGKA TEORITIS DAN PENGEMBANGAN HIPOTESIS}

\section{Kewirausahaan}

Zimmerer dan Scarborough, (2005:115) memberi konsep wirausaha sebagai berikut: An entrepreneur is one who creates a new business in face of risk and uncertainty for the purpose of achieving profit and growth by identyfying significant opportunities an assembling the necessary resources to capitalize on them. Konsep tersebut mengindikasikan bahwa wirausahawan merupakan seorang yang menghadapi risiko di masa mendatang dan bertumbuh untuk mendapatkan profit dengan mengunakan seluruh sumber daya yang dimiliki sehingga mengalami peningkatan terhadap usaha. Berarti wirausahawan diharapkan mampu untuk menciptakan inovasi, kreatif dan mempunyai motivasi yang tinggi untuk mencapai keberhasilan usaha. Demikian pula dengan risiko yang dihadapi, penuh dengan tantangan yang akibatnya dapat menjadi semanagat dalam meningkatkan kinerja.

Yaghoobi et al. (2010) menyatakan bahwa wirausahawan adalah orang yang berani membuka kegiatan produktif yang mandiri. Jong and Wennekers (2008) menyatakan bahwa kewirausahaan dapat didefinisikan sebagai pengambilan risiko untuk menjalankan usaha sendiri dengan memanfaatkan peluang-peluang untuk menciptakan usaha baru atau dengan pendekatan yang inovatif sehingga usaha yang dikelola berkembang menjadi besar dan mandiri dalam menghadapi tantangantantangan persaingan. Pengambilan risiko, menjalankan usaha sendiri, memanfaatkan peluang-peluang, menciptakan usaha baru, inovatif, mandiri merupakan kunci keberhasilan kewirausahaan. Inovatif merupakan salah satu kunci utama dalam menciptakan usaha baru, sehingga tidak menimbulkan kejenuhan dan mampu menjadi pendorong dalam melakukan kegiatan usaha bagi pelaku usaha kecil. Jiwa kewirausahaan dituntut untuk mengembangkan diri menjadi kekuatan yang tangguh dalam melaksanakan kegiatan usaha.

Berwirausaha berarti memiliki kemampuan menemukan dan mengevaluasi peluang-peluang, mengumpulkan sumber-sumber daya yang diperlukan dan bertindak 
untuk memperoleh keuntungan dari peluang tersebut (Meredith 2005:4). Wirausahawan memiliki risiko atas finansialnya sendiri atau finansial orang lain yang dipercayakan kepadanya dalam memulai suatu pekerjaan, selain itu juga berisiko atas keteledoran dan kegagalan usahanya. Sebaliknya, manajer lebih termotivasi oleh tujuan yang dibebankan dan kompensasi (gaji danbenefit lainnya) yang akan diterimanya. Seorang manajer cenderung kurang toleran terhadap sesuatu yang tidak pasti dan membingungkan dan kurang berorientasi terhadap risiko dibandingkan dengan wirausahawan. Manajer lebih memilih gaji dan posisi yang relatif aman dalam bekerja. Wirausahawan lebih memiliki keahlian intuisi dalam mempertimbangkan suatu kemungkinan atau kelayakan dan perasaan dalam mengajukan sesuatu kepada orang lain. Dilain pihak, manajer memiliki keahlian yang rasional dan orientasi yang terperinci (rational and detailed oriented skills). Wirausaha berani mengambil risiko untuk menjalankan sendiri dengan memanfaatkan peluang-peluang untuk menciptakan usaha baru atau dengan pendekatan yang inovatif sehingga usaha yang dikelola berkembang menjadi besar dan mandiri tidak bergantung kepada pemerintah atau pihak-pihak lain dalam menghadapi segala tantangan persaingan. Konsep dari kewirausahaan adalah pengambilan risiko, menjalankan sendiri, memanfaatkan peluang-peluang, menciptakan baru, pendekatan yang inovatif dan mandiri. Baldacchino (2008) menyatakan bahwa kewirausahaan adalah kemampuan kreatif dan inovatif yang dijadikan dasar, kiat dan sumber daya untuk mencari peluang menuju sukses. Kewirausahaan merupakan kemampuan untuk menciptakan sesuatu yang baru dan berbeda melalui berpikir kreatif, bertindak inovatif dan menimbulkan motivasi untuk menciptakan peluang.

\section{Kreativitas}

Kreativitas merupakan inisiatif terhadap suatu produk atau proses yang bermanfaat, benar, tepat dan bernilai terhadap suatu tugas yang lebih bersifat heuristik yaitu sesuatu yang merupakan pedoman, petunjuk, atau panduan yang tidak lengkap yang akan menuntun untuk mengerti, mempelajari, atau menemukan sesuatu yang baru. Kreatif adalah terbuka terhadap pengalaman, suka memperhatikan melihat sesuatu dengan cara yang tidak biasa, kesungguhan, menerima dan merekonsiliasi sesuatu yang bertentangan, toleransi terhadap sesuatu yang tidak jelas, independen dalam mengambil keputusan, berpikir dan bertindak, memerlukan dan mengasumsikan otonomi, percaya diri, tidak menjadi subjek dari standar dan kendali kelompok, rela mengambil risiko yang diperhitungkan, gigih, sensitif terhadap permasalahan, lancar dan mampu untuk menggeneralisasikan ide-ide yang banyak, fleksibel, keaslian, responsif terhadap perasaan, terbuka terhadap fenomena yang belum jelas, motivasi, bebas dari rasa takut gagal, berpikir dalam imajinasi, selektif. Pemahaman atas kreativitas (daya cipta) akan memberikan dasar yang kuat untuk membuat modul atau perangkat tentang kewirausahaan. Peran sentral dalam kewirausahaan adalah adanya kemampuan yang kuat untuk menciptakan (to create or to innovate) sesuatu yang baru, misalnya: sebuah organisasi baru, pandangan baru tentang pasar, nilai-nilaicorporate baru, proses-proses manufacture yang baru, 
produk-produk dan jasa-jasa baru, cara-cara baru dalam mengelola sesuatu, cara-cara baru dalam pengambilan keputusan.

Suryana (2003:63) menyatakan bahwa kreativitas adalah:

"Berpikir sesuatu yang baru. Kreativitas sebagai kemampuan untuk mengembangkan ide-ide baru dan untuk menemukan cara-cara baru dalam memecahkan persoalan dalam menghadapi peluang".

Kreativitas merupakan suatu topik yang relevan tidak hanya bagi wirausaha yang baru memulai, tetapi juga bagi bisnis dan kegiatan bisnis pada umumnya. Kreativitas merupakan sumber penting dalam penciptaan daya saing untuk semua organisasi yang peduli terhadapgrowth (pertumbuhan) danchange (perubahan).

Roe (dalam Frinces2004) menyatakan bahwa syarat-syarat orang yang kreatif yaitu: keterbukaan terhadap pengalaman (openness to experience), pengamatan melihat dengan cara yang biasa dilakukan (observance seeing things in unusual ways), keinginan tahu (curiosity) Toleransi terhadap ambiguitas (tolerance of ambiguity), kemandirian dalam penilaian, pikiran dan tindakan (independence in judgement, thought and action), memerlukan dan menerima otonomi (needing and assuming autonomy), kepercayaan terhadap diri sendiri (self-reliance), tidak sedang tunduk pada pengawasan kelompok (not being subject to group standart and control), ketersediaan untuk mengambil risiko yang diperhitungakan (willing to take calculated risks).

\section{Inovasi}

Karakter yang penting dalam wirausahawan adalah kemampuan berinovasi (Larsen and Lewis 2007). Perusahaan tidak akan dapat bertahan apabila tanpa inovasi. Kondisi ini disebabkan karena adanya kebutuhan, keinginan dan permintaan pelanggan berubah-ubah. Konsumen tidak selamanya akan menggunakan produk yang sama, karena konsumen akan mencari produk lain dari perusahaan yang dirasakan dapat memuaskan kebutuhannya. Konsumen perlu adanya inovasi secara terus menerus jika perusahaan berkeinginan untuk dapat berlangsung lebih lama. Inovasi merupakan sesuatu yang berkenaan dengan barang, jasa atau ide yang dapat dirasakan baru oleh seseorang. Ide yang telah lama ada dapat dikatakan suatu inovasi bagi orang yang baru melihat atau merasakan. Perusahaan dapat melakukan inovasi dalam bidang: inovasi produk (barang, jasa, ide dan tempat), inovasi manajemen (proses kerja, proses produksi, keuangan pemasaran dan sebagainya). Inovasi perlu memperhatikan prinsip-prinsip sebagai berikut: menganalisi peluang, apa yang harus dilakukan untuk memuaskan peluang, sederhana dan terarah, dimulai dari yang kecil dan kepemimpinan. Hills (2008) mendefinisi inovasi sebagai ide, praktik atau objek yang dianggap baru oleh seorang individu atau unit pengguna lainnya. Suryana (2003:86) inovasi yaitu "sebagai kemampuan untuk menerapkan kreativitas dalam rangka memecahkan persoalan dan peluang untuk meningkatkan dan memperkaya kehidupan". 
Keehet al. (2007) menjelaskan inovasi sangat penting karena terdapat alasan berikut: (1) Teknologi berubah sangat cepat seiring adanya produk baru, proses dan layanan baru dari pesaing, dan ini mendorong usaha entrepreneurial untuk bersaing dan sukses, yang harus dilakukan adalah menyesuaikan diri dengan inovasi teknologi baru; (2) efek perubahan lingkungan terhadap siklus hidup produk semakin pendek, artinya bahwa produk atau layanan lama harus digantikan dengan yang baru dalam waktu cepat, dan ini bisa terjadi karena ada pemikiran kreatif yang menimbulkan inovasi; (3) konsumen saat ini lebih pintar dan menuntut pemenuhan kebutuhan. Harapan dalam pemenuhan kebutuhan mengharap lebih dalam hal kualitas, pembaruan dan harga. Oleh karena itu,skill inovatif dibutuhkan untuk memuaskan kebutuhan konsumen sekaligus mempertahankan konsumen sebagai pelanggan; (4) dengan pasar dan teknologi yang berubah sangat cepat, ide yang bagus dapat semakin mudah ditiru, dan ini membutuhkan metode penggunaan produk, proses yang baru dan lebih baik dan layanan yang lebih cepat secara terus menerus; (5) inovasi bisa menghasilkan pertumbuhan lebih cepat, meningkatkan segmen pasar, dan menciptakan posisi korporat yang lebih baik. Proses kewirausahaan, inovasi dan kinerja dapat dilihat pada Gambar 1.

\section{Kinerja Karyawan}

Kinerja merupakan hasil yang dicapai seseorang menurut ukuran yang berlaku untuk pekerjaan yang bersangkutan (Moh. As'ad 2003:48). Mangkunegara (2005:67) mengatakan bahwa kinerja adalah hasil kerja secara kualitas dan kuantitas yang dicapai oleh seorang karyawan dalam melaksanakan tugasnya sesuai dengan tanggung jawab yang diberikan kepadanya. Kinerja dalam hal ini menunjukkan hasil kerja yang dicapai seseorang setelah melaksanakan tugas pekerjaan yang dibebankan oleh organisasi. Sedangkan ukuran baik tidaknya hasil kerja dapat dilihat dari mutu atau kualitas yang dicapai karyawan sesuai dengan tuntutan organisasi. Kinerja dapat dicapai dengan baik apabila karyawan mampu bekerja sesuai dengan standar penilaian yang ditetapkan organisasi. Berdasarkan uraian di atas dapat disimpulkan bahwa pengertian kinerja adalah hasil kerja yang dicapai seseorang karyawan terhadap pelaksanaan tugas perkerjaan yang dinilai berdasarkan pada kriteria atau standar penilaian tertentu. Istilah kinerja sering digunakan untuk menyebut tingkat keberhasilan individu atau kelompok. Kinerja bisa diketahui jika individu atau kelompok individu tersebut mempunyai kriteria keberhasilan yang telah ditetapkan. Kinerja dapat meningkat apabila dilandasi dengan motivasi yang tinggi. 


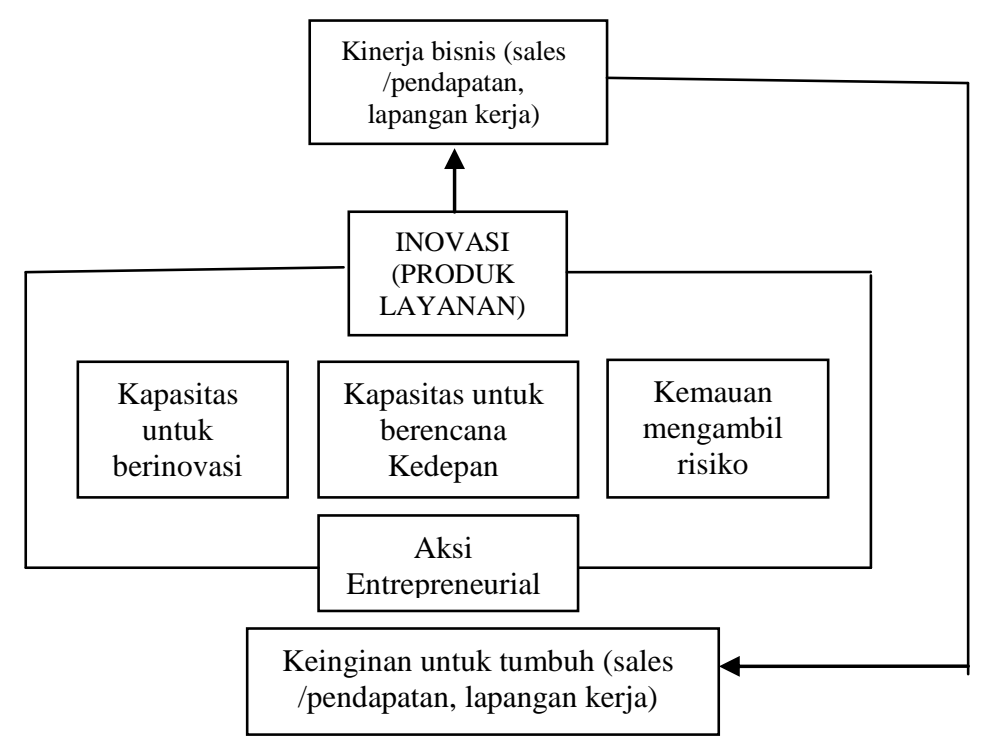

Gambar 1

Proses Entrepreneurial, Inovasi dan Kinerja Bisnis

\section{Motivasi}

Haynes dan Massie dalam Manulang (2001:63) mengatakan "motive is a something within the individual which incities him to action" maksudnya bahwa motif atau dorongan batin adalah suatu dorongan yang menjadi pangkal seseorang untuk melakukan sesuatu atau bekerja. Kast dan Rosenzweig (1995:67) mendefinisi motif adalah apa yang menggerakkan seseorang untuk bertindak dengan cara tertentu atau sekurang-kurangnya mengembangkan suatu kecenderungan tertentu. Motivasi dapat pula berarti sebagai faktor yang mendorong orang untuk bertindak dengan cara tertentu. Hasibuan (2005:85) motivasi mempersoalkan bagaimana caranya mendorong gairah kerja bawahan, agar mereka mau bekerja keras denganmemberikan semua kemampuan dan keterampilannya untuk mewujudkan tujuan organisasi. Oleh karena itu, kinerja karyawan akan meningkat apabila terdapat motivasi pada diri karyawan.

Berendoom dan Stainer dalam Sedarmayanti (2001:124) mendefinisi motivasi adalah kondisi mental yang mendorong aktivitas dan memberi energi yang mengarah kepada pencapaian kebutuhan memberi kepuasan atau mengurangi ketidakseimbangan. Hasibuan (2005:87) mendefinisikan motivasi adalah pemberian daya penggerak yang menciptakan kegairahan kerja seseorang, agar mereka mau bekerja sama, efektif dan terintegrasi dengan segala upayanya untuk mencapai kepuasan. Pinder dalam Donovan (2001) menyebut motivasi adalah a set of energetic forces that originates both within as well as beyond an individual's being, to initiate 
work-related behaviour, and to determine its form, direction, intensity, and duration".Dengan demikian, motivasi adalah sekelompok pendorong yang mempunyai ciri-ciri sebagai berikut: (1) berasal baik dari dalam maupun dari luar individu; (2) dapat menimbulkan perilaku bekerja; dan (3) juga dapat menentukan bentuk, tujuan, intensitas dan lamanya perilaku bekerja. Mc. Mahon (1986) dalam Djalali (2001:107) menyatakan bahwa motivasi merupakan suatu proses yang mengarah pada pencapaian suatu tujuan. Teevan dan Smith (1976) dalamDjalali (2001:108) mengemukakan bahwa motivasi adalah suatu konstruksi yang mengaktifkan dan mengarahkan perilaku dengan cara memberi dorongan atau daya pada organisme untuk melakukan aktivitas. Motivasi pada dasarnya merupakan penggerak, alasan, dorongan yang ada di dalam diri manusia yang menyebabkan orang itu berbuat sesuatu. Motif merupakan dorongan, keinginan, hasrat dan tenaga penggerak yang berasal dari dalam diri manusia untuk berbuat atau melakukan sesuatu (Wursanto 2005:47). Motivasi kerja adalah sesuatu yang menimbulkan dorongan atau semangat kerja.

\section{Usaha Kecil}

UMKM adalah sebagai berikut: (1) Usaha mikro adalah usaha produktif milik orang perorangan dan/atau badan usaha perorangan yang memenuhi kriteria usaha mikro sebagaimana diatur dalam Undang-Undang ini; (2) Usaha kecil adalah usaha ekonomi produktif yang berdiri sendiri, yang dilakukan oleh orang perorangan atau badan usaha yang bukan merupakan anak perusahaan atau bukan cabang perusahaan yang dimiliki, dikuasai, atau menjadi bagian baik langsung maupun tidak langsung dari usaha menengah atau usaha besar yang memenuhi kriteria usaha kecil sebagaimana dimaksud dalam Undang-Undang ini; (3) Usaha menengah adalah usaha ekonomi produktif yang berdiri sendiri, yang dilakukan oleh orang perseorangan atau badan usaha yang bukan merupakan anak perusahaan atau cabang perusahaan yang dimiliki, dikuasai, atau menjadi bagian baik langsung maupun tidak langsung dengan usaha kecil atau usaha besar dengan jumlah kekayaan bersih atau hasil penjualan tahunan sebagaimana diatur dalam Undang-Undang ini.

\section{Kriteria UMKM}

Berdasarkan UU Usaha Mikro Kecil Menengah (UMKM) No.20 Tahun 2008 pada Bab IV pasal 16 menetapkan kriteria UMKM sebagai berikut: Kriteria usaha mikro: (a) memiliki kekayaan bersih paling banyak Rp50.000.000,00 (lima puluh juta rupiah) tidak termasuk tanah dan bangunan tempat usaha; atau; (b) memiliki hasil penjualan tahunan paling banyak Rp300.000.000,00 (tiga ratus juta rupiah).

Kriteria Usaha Kecil: memiliki kekayaan bersih lebih dari Rp50.000.000,00 sampai paling banyak Rp500.000.000,00 tidak termasuk tanah dan bangunan tempat usaha; atau memiliki hasil penjualan tahunan lebih dari Rp300.000.000,00 sampai dengan paling banyak Rp2.500.000.000,00.

Kriteria Usaha Menengah adalah memiliki kekayaan bersih lebih dari Rp500.000.000,00 sampai dengan paling banyak Rp10.000.000.000,00 tidak 
termasuk tanah dan bangunan tempat usaha atau memiliki hasil penjualan tahunan lebih dari Rp2.500.000.000,00 sampai dengan paling banyak Rp50.000.000.000,00.

\section{Hubungan antara Kreativitas, Inovasi, Motivasi, Kinerja dan Kewirausahaan.}

Hasil penelitian Hadiyati (2011) kreativitas meliputi terbuka terhadap pengalaman, suka memperhatikan melihat sesuatu dengan cara yang tidak biasa, kesungguhan, menerima dan merekonsiliasi sesuatu yang bertentangan, toleransi terhadap sesuatu yang tidak jelas, independen dalam mengambil keputusan, berpikir dan bertindak, memerlukan dan mengasumsikan otonomi, percaya diri, tidak menjadi subjek dari standar dan kendali kelompok, rela mengambil risiko yang diperhitungkan, gigih, sensitif terhadap permasalahan, lancar kemampuan untuk menarik ide-ide, fleksibel keaslian, responsif terhadap perasaan, terbuka terhadap fenomena yang belum jelas, motivasi, bebas dari rasa takut gagal, berpikir dalam imajinasi, selektif dan inovasi meliputi: menganalisis peluang, apa yang harus dilakukan untuk memuaskan peluang, sederhana dan terarah dimulai dari yang kecil, berpengaruh secara parsial terhadap variabel kewirausahaan. Inovasi berpengaruh secara parsial terhadap variabel kewirausahaan, kreatifitas dan inovasi berpengaruh secara simultan terhadap kewirausahaan dengan variabel inovasi memiliki pengaruh yang lebih besar terhadap kewirausahaan.

Berdasarkan hasil penelitian Sihotang (2011), kreativitas, inovasi dan motivasi seorang pengusaha pribumi berpengaruh langsung terhadap kinerja dalam menjalankan usaha. Penelitian ini dilakukan di Jakarta, Bandung dan Medan bagi pengusaha pribumi. Setiap pengusaha memiliki rasa kreativitas, inovasi dan motivasi dalam kinerja untuk menjalankan usaha. Burtonet al., (2002) motivasi kerja sangat penting karena menjelaskan mengapa karyawan bersedia dengan baik saat melakukan pekerjaan. Kebutuhan adalah faktor pendorong dalam motivasi kerja dengan demikian, tujuan seseorang untuk bekerja adalah untuk memperoleh pendapatan dan memenuhi kebutuhannya, dengan harapan, keinginan dan harapan yang dapat diwujudkan ditempat kerjanya. Motivasi kerja yang besar pada setiap karyawan diharapkan dapat mengarahkan sikap dan tindakan dari berbagai tujuan individu yang dimilikinya, sehingga mampu mengesampingkan tujuan pribadi dan sanggup bekerja dengan baik, efektif, efisien dan memiliki kinerja yang tinggi sesuai dengan tujuan organisasi.

Berdasarkan landasan teori dan hasil penelitian terdahulu maka dapat disusun hipotesis sebagai berikut:

H1: Kreativitas, inovasi dan motivasi berpengaruh positif dan signifikan terhadap kinerja karyawan.

H2: Kreativitas, inovasi dan motivasi berpengaruh positif dan signifikan terhadap pengembangan kewirausahaan.

H3: Kinerja karyawan berpengaruh positif dan signifikan terhadap pengembangan kewirausahaan.

\section{Pengembangan Model}


Berdasarkan masalah penelitian dan kajian pustaka, kerangka penelitian dipaparkan pada Gambar2.Pengembangan kewirausahaan akan semakin meningkat apabila kinerja karyawan meningkat, didasari dengan peningkatan kinerja karyawan yang dipengaruhi adanya peningkatan kreativitas, inovasi dan motivasi.

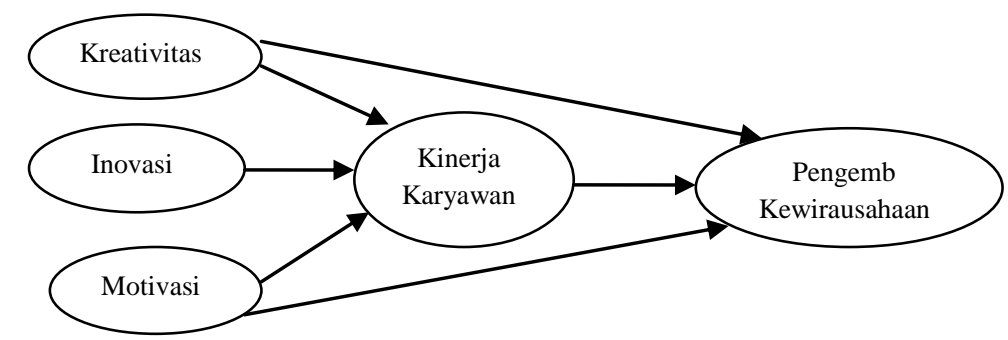

Gambar 2

Model Penelitian

\section{METODA PENELITIAN}

Penelitian ini merupakan penelitian explanatory research yang menguji pengaruh antara variabel bebas yaitu variabel kreativitas, inovasi dan motivasi. Variabel antara (endogen) yaitu variabel pengembangan kewirausahaan dan kinerja karyawan sebagai variabel mediasi (Arikunta 2006:29).

\section{Populasi dan Sampel}

Populasi dalam penelitian ini adalah karyawan perusahaan kecil jenang kudus di kabupaten Kudus terdiri dari 396 perusahaan dengan jumlah tenaga kerja 2768 karyawan. Karena keterbatasan yang ada, maka tidak semua populasi diteliti. Jumlah sampel yang diambil 86 karyawan, dengan menggunakan metodapurposive sample, yaitu cara pengambilan subjek bukan didasarkan atas strata, random atau daerah tetapi didasarkan atas adanya tujuan tertentu(Arikunto 2006:140). Sampel ditentukan dengan syarat bahwa karyawan masih aktif, masa kerja sekurang-kurangnya lima tahun, usia maksimum lima puluh tahun dan pendidikan serendah-rendahnya SMP. Selain itu perusahaan masih aktif dan terdaftar pada Dinas Koperasi dan UMKM Kabupaten Kudus.

\section{Tehnis Analisis Data}

Pengujian hipotesis menggunakan teknis analisis SEM atau Structural Equation Modelling yang dioperasikan melalui program AMOS. Model struktural sebagai berikut.

$$
\begin{aligned}
& \mathrm{KK}=\alpha \mathrm{o}+\alpha_{1} \mathrm{Kr}+\alpha_{2} \operatorname{In}+\alpha_{3} \mathrm{Mo}+\varepsilon_{1} . \\
& \mathrm{PK}=\beta \mathrm{o}+\beta_{1} \mathrm{Kr}+\beta_{2} \mathrm{In}+\beta_{3} \mathrm{Mo}+\varepsilon_{2} . \\
& \mathrm{PK}=\beta \mathrm{o}+\beta_{1} \mathrm{KK}+\varepsilon_{3} \ldots \ldots \ldots \ldots \ldots \ldots \ldots \ldots \ldots \ldots \ldots \ldots \ldots \ldots \ldots
\end{aligned}
$$


Keterangan:

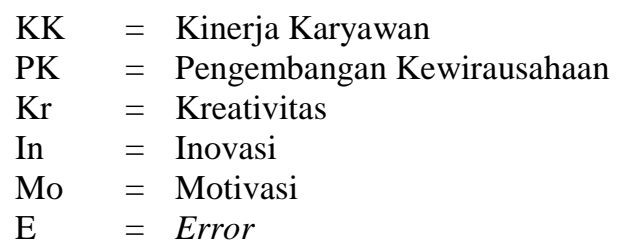

Komponen-komponen ukuran mengidentifikasi latent variables dan komponen-komponen struktural mengevaluasi hipotesis hubungan kausal, antara latent variables pada model kausal dan menunjukkan sebuah pengujian seluruh hipotesis dari model sebagai satu keseluruhan (Ferdinand 2002:126).

\section{HASIL DAN PEMBAHASAN}

\section{Hasil Analisis}

\section{Analisis Full Structural Equation Model}

Berdasarkan hasil evaluasi atas asumsi-asumsi SEM, analisis selanjutnya adalah evaluasi atas kesesuaian model yang diajukan dalam penelitian ini dengan berbagai kriteria goodness-of-fit. Hasil revisi model menghasilkan tingkat kesesuaian model cukup baik. Untuk evaluasi kriteria goodness-of-fit index, dapat dilihat pada Tabel 2.

Tabel 2

Evaluasi Kriteria Goodness-Of-Fit

\begin{tabular}{lccc}
\hline \multicolumn{1}{c}{ Kriteria } & Nilai Kritis & $\begin{array}{c}\text { Model } \\
\text { Penelitian }\end{array}$ & Evaluasi Model \\
\hline$\chi^{2}$ (Chi-Square $)$ & $\begin{array}{c}\text { Diharapkan } \\
\text { kecil }\end{array}$ & 293,915 & \\
Probability & $\geq 0,05$ & 0,108 & Baik \\
RMSEA & $\leq 0,08$ & 0,012 & Baik \\
GFI & $\geq 0,90$ & 0,865 & Cukup Baik \\
AGFI & $\geq 0,90$ & 0,784 & Cukup Baik \\
CMIN/DF & $\leq 2,00$ & 1,285 & Baik \\
TLI & $\geq 0,95$ & 0,816 & Baik \\
\hline
\end{tabular}

Sumber: Data awal diolah, 2011

Dari Tabel 2 ditunjukkan perbandingan indeks uji hipotesis yang dihasilkan dengan kriteria goodness-of-f fit index. Pengujian model penelitian menghasilkan konfirmasi yang baik atas hubungan-hubungan kausalitas antar variabel.

\section{Uji Hipotesis}

Berdasarkan Tabel3 menunjukkan nilai C.R yang identik dengan t-hitung, pada hasil pengolahan dibandingkan dengan nilai kritisnya yaitu $\pm 1,96$ pada tingkat signifikansi 0,05 (5\%)seperti yang terlihat dalam Tabel 3. 
Persamaan model matematik dalam bentuk Structural Equation Model (SEM) sebagai berikut:

$Y_{1}=0,248 X_{1}+0,467 X_{2}+0,342 X_{3}+\varepsilon_{1}, R^{2}=0,382 \ldots \ldots \ldots \ldots \ldots \ldots \ldots \ldots \ldots \ldots \ldots$
$Y_{2}=0,236 X_{1}+0,228 X_{2}+0,184 X_{3}+0,826 Y_{1}+\varepsilon_{2}, R^{2}=0,624$

Tabel 3

Hasil Estimasi Parameter Pengaruh Langsung antar Variabel Berdasarkan Model SEM

\begin{tabular}{cclccc}
\hline No & $\begin{array}{c}\text { Variabel } \\
\text { Berpengaruh }\end{array}$ & \multicolumn{1}{c}{ Variabel Dipengaruhi } & $\begin{array}{c}\text { Nilai } \\
\text { Estimasi }\end{array}$ & $\begin{array}{c}\text { Thitung/ } \\
\text { C.R }\end{array}$ & P(2 tail $)$ \\
\hline 1. & Kreativitas $\left(\mathrm{X}_{1}\right)$ & Kinerja $\left(\mathrm{Y}_{1}\right)$ & 0,248 & 2,868 & 0,000 \\
& & Kewirausahaan $\left(\mathrm{Y}_{2}\right)$ & 0,236 & 2,182 & 0,000 \\
2. & Inovasi $\left(\mathrm{X}_{2}\right)$ & Kinerja $\left(\mathrm{Y}_{1}\right)$ & 0,467 & 2,794 & 0,018 \\
& & Kewirausahaan $\left(\mathrm{Y}_{2}\right)$ & 0,228 & 2,308 & 0,000 \\
2. & \multirow{2}{*}{ Motivasi $\left(\mathrm{X}_{3}\right)$} & Kinerja $\left(\mathrm{Y}_{1}\right)$ & 0,342 & 3,195 & 0,000 \\
& & Kewirausahaan $\left(\mathrm{Y}_{2}\right)$ & 0,184 & 1,564 & 0,000 \\
3. Kinerja $\left(\mathrm{Y}_{1}\right)$ & Kewirausahaan $\left(\mathrm{Y}_{2}\right)$ & 0,826 & 3,716 & 0,101 \\
& & & & & \\
\hline
\end{tabular}

Sumber: Data awal diolah, 2011

Nilai kritis $\pm 1,96$ dan signifikan $5 \%$.

Nilai squared multiple correlation pada persamaan pertama adalah 0,382 mengindikasikan bahwa 38,2 persen dari variasi nilai kinerja karyawan ditentukan oleh variasi kreativitas, inovasi dan motovasi. Nilai squared multiple correlation pada persamaan kedua adalah 0,624 mengindikasikan bahwa 62,4 persen dari variasi nilai pengembangan kewirausahaan ditentukan oleh variasi nilai kreativitas, inovasi dan motivasi dan kinerja karyawan. Pengaruh langsung dan tidak langsung tersebut ditampilkan dalam Tabel 4.

Tabel 4

Hasil Pengujian Hipotesis (Pengaruh langsung/Direct)

\begin{tabular}{clc}
\hline & \multicolumn{1}{c}{ Hipotesis } & Kesimpulan \\
\hline $\mathrm{H}_{1}$ & $\begin{array}{l}\text { Kreativitas, inovasi, dan motivasi mempunyai pengaruh } \\
\text { yang signifikan terhadap kinerja karyawan. }\end{array}$ & Didukung \\
$\mathrm{H}_{2}$ & $\begin{array}{l}\text { Kreativitas, inovasi dan motivasi mempunyai pengaruh } \\
\text { yang signifikan terhadap pengembangan kewirausahaan. }\end{array}$ & Didukung \\
$\mathrm{H}_{3}$ & $\begin{array}{l}\text { Kinerja karyawan mempunyai pengaruh yang signifikan } \\
\text { dengan pengembangan kewirauswahaan. }\end{array}$ & Didukung \\
\hline
\end{tabular}

\section{PEMBAHASAN}

\section{Hasil Pengujian Hipotesis}


Hasil pengujian hipotesis dan analisis pengaruh, diuraikan seperti ditunjukkan pada Tabel 5. Sedangkan hasil rekap pengaruh tidak langsung ditunjukkan pada Tabel 6.

Tabel 5

Pengaruh Langsung dan Tidak Langsung

Pengaruh Tidak Langsung (Indirect)

\begin{tabular}{lrrrrr}
\hline & Kreativitas & Inovasi & Motivasi & $\begin{array}{c}\text { Kinerja } \\
\text { Karyawan }\end{array}$ & $\begin{array}{r}\text { Pengembangan } \\
\text { kewirausahaan }\end{array}$ \\
\hline Kinerja Karyw & 0,000 & 0,000 & 0,000 & 0,000 & 0,000 \\
Peng. Kewr & 0,146 & 0,182 & 0,214 & 0,000 & 0,000 \\
& Kreativita & \multicolumn{2}{c}{ Pengaruh Total (Total Effect) } & Kinerja & $\begin{array}{r}\text { Pengembangan } \\
\text { kewirausahaan }\end{array}$ \\
Kinerja & S & Inovasi & Motivasi & Karyawan & 0,000 \\
Karyw & 0,262 & 0,258 & 0,326 & 0,000 & 0,000 \\
Peng. Kewr & 0,314 & 0,362 & 0,427 & 0,643 &
\end{tabular}

Sumber : Data Penelitian diolah, 2011.

Tabel 6

Hasil Pengujian Hipotesis (Pengaruh Tidak langsung/Indirect)

\begin{tabular}{clll}
\hline & \multicolumn{1}{c}{ Hipotesis } & Kesimpulan \\
\hline a $\quad \begin{array}{l}\text { Kreativitas berpengaruh positif dan signifikan terhadap } \\
\text { pengembangan kewirausahaan melalui kinerja karyawan. }\end{array}$ & Signifikan \\
b $\quad \begin{array}{l}\text { Inovasi berpengaruh positif dan signifikan terhadap } \\
\text { pengembangan kewirausahaan melalui kinerja karyawan }\end{array}$ & Signifikan \\
c $\quad \begin{array}{l}\text { Motivasi berpengaruh positif dan signifikan terhadap } \\
\text { pengembangan kewirausahaan melalui kinerja karyawan }\end{array}$ & Signifikan \\
\hline
\end{tabular}

\section{Pengaruh Kreativitas, Inovasi dan Motivasi terhadap Kinerja Karyawan.}

Kreativitas berpengaruh positif dan signifikan terhadap kinerja karyawan yang ditunjukkan nilai 0,248 artinya bahwa kreativitasmerupakan salah satu kebutuhan yang diperlukan oleh seorang karyawan untuk dapat mencapai peningkatan kinerja yang tinggi meskipun menurut sifatnya kinerja karyawan besarannya sangat relatif antara yang satu dengan lainnya, tergantung dari kemampuan minimal yang dimiliki masing-masing individu. Secara keseluruhan, responden menyatakan bahwa selama bekerja kinerjanya merasa meningkat dengan adanya kreativitasyang terbentuk dari kemampuan dan pengembangan masing-masingkayawan.Hasil penelitian ini mendukung hasil penelitian Sihotang (2011). 
Inovatif berpengaruh positifdan signifikanterhadap kinerja karyawan yaitu ditunjukkan dengan nilai 0,467 yang artinya hasil dari pengembangan inovasi yang dijalankan karyawan mempunyai dampak yang selalu positif bagi kinerja karyawan pada perusahaan, sebab semakin tinggi pengembangan inovasi dilakukan, maka akan berdampak pada peningkatan kinerja karyawan dari waktu ke waktudalam aktivitas perusahaan. Pelaksanaan pengembangan inovasi yang lebih banyak ke arah karyawan akan menyebabkan seorang karyawan dapat mencapai kinerja yang tinggi.Hasil penelitian ini mendukungteori inovasi yang dikemukakan oleh Larsen and Lewis (2007), Hills (2008), Suryana (2003) dan Keehet al. (2007).

Motivasi berpengaruh positif dan signifikan terhadap kinerja karyawan yang ditunjukkan dengan nilai 0,342 artinya motivasi merupakan suatu konsep yang bisa dijadikan sarana untuk menguatkan kemampuan karyawan dalam mencapai tujuan organisasi, karena tanpa adanya motivasi yang tinggi dari para karyawan maka semakin tidak akan mampu menciptakan kinerja yang tinggi pula. Aspek motivasi akan berdampak pada kesadaran karyawan untuk dapat melakukan pekerjaan dengan ikhlas tanpa merasa dipaksakan, akibatnya berdapak pada produktivitas yang tinggi bagi masing-masing karyawan. Hasil penelitian ini mendukung pendapat tentang motivasi yang dikemukakan oleh Haynes dan Massie dalam Manulang (2001:63), Hasibuan (2005:85).

\section{Pengaruh Kreativitas, Inovasi, Motivasi terhadap Pengembangan Kewirausahaan}

Kreativitas berpengaruh positif dan signifikanterhadap pengembangan kewirausahaan yang ditunjukkan nilai 0,236 artinya kreativitas berpengaruh positif dan signifikan terhadap kinerja karyawan akan mempengaruhi terbentuknya pengembangan jiwa kewirausahaan bagi karyawan itu sendiri. Ditunjukkan pula bahwa kreativitas juga berpengaruh tidak langsung terhadap pengembangan kewirausahaan dengan nilai 0,146 melalui kinerja karyawan, artinya peningkatan pengembangan kewirausahaan dipengaruhi oleh kreativitas melalui kinerja karyawan.

Kondisi ini dapat terjadi karena karyawan yang kinerjanya tinggi telah diakui dan didukung kreativitasnya oleh perusahaan dapat melakukan pengembangan kewirausahaan secara optimal bagi dirinya sendiri. Belum terbentuknya kewirausahaan secara optimal seorang karyawan karena dibatasi oleh adanya keterbatasan untuk menciptakan kreativitas dalam mengembangkan usaha, karyawan yang telah mempunyai kinerja tinggi merasa bahwa tidak perlu lagi untuk mengembangkan diri dalam melakukan bentukan-bentukan baru, artinya apabila terdapat pekerjaan yang sudah dapat diselesaikan pada waktunya, karyawan tidak perlu mencari peluang baru agar perusahaan menjadi lebih berkembang. Tetapi sebaliknya pihak manajemen menentukan bahwa sesuai ketentuan yang ada maka setiap karyawan diperkenankan melakukan pengembangan individu untuk memajukan perusahaan, sehingga akan tercipta kewirausahaan yang baru. Kondisi ini 
salah satunya menjadi suatu pertimbangan dan alasan bahwa kreativitas berpengaruh signifikan terhadap kinerja pegawai serta kreativitas berpengaruh signifikan terhadap pengembangan kewirausahaan.

Inovasiberpengaruh positif dan signifikan terhadap pengembangan kewirausahaan dengan nilai 0,228artinya inovasi merupakan suatu upaya untuk menggerakkankaryawan melalui proses terbarukan untuk mencapai tujuan organisasi, diharapkan inovasi dapat menimbulkan perubahan positif berupa kekuatan dinamis yang dapat mengkoordinasikan organisasi dalam rangka mencapai tujuan jika diterapkan sesuai dengan koridor yang telah ditetapkan kedua belah pihak sesuai dengan jabatan yang dimiliki. Selain itu motivasi juga berpengaruh tidak langsung terhadap pengembangan kewirausahaan $(0,182)$, berarti peningkatan pengembangan kewirausahaan dipengaruhi oleh peningkatan inovasi melalui kinerja karyawan yang meningkat. Hasil penelitian ini mendukung pendapat dan teori tentang inovasi yang dikemukakan olehLarsen and Lewis (2007).

Motivasi mempunyai pengaruh positif dan signifikan terhadap pengembangan kewirausahaan yang ditunjukkan dengan nilai 0,184 artinya bahwa motivasi merupakan proses yang mengarah pada pencapaian suatu tujuan yang mempengaruhi kelompok-kelompok orang dalam lingkungan organisasi, akan membentuk suatu persepsi subyektif keseluruhan mengenai organisasi berdasarkan pada faktor-faktor seperti toleransi, risiko, tekanan pada tim dan dukungan orang, persepsi keseluruhan ini akan menjadi kepribadian organisasi yang mampu mendukung dan mempengaruhi kinerja karyawan serta dampaknya pada kebiasaan kerja sama yang kuat. Motivasi juga berpengaruh tidak langsung terhadap pengembangan kewirausahaan melalui kinerja karyawan $(0,214)$, artinya bahwapeningkatan motivasi akan berpengaruh terhadap peningkatan pengembangan kewirausahaan melalui peningkatan kinerja karyawan. Motivasi pada dasarnya merupakan penggerak, alasan, dorongan yang ada di dalam diri manusia yang menyebabkan orang itu berbuat sesuatu. Hasil penelitian ini mendukung teori tentang motivasi yang dikemukakan oleh Mc Mahon dan Mc Mahon (1986) dalam Djalali (2001:107), Teevan dan Smith (1976) dalam Djalali (2001:108), Wursanto (2005:47).

\section{Pengaruh Kinerja Karyawan terhadap Pengembangan Kewirausaan}

Kinerja karyawan berpengaruh positif dan signifikan terhadap pengembangan kewirausahaan, artinya bahwa secara umum kinerja karyawan yang tinggi akan mampu meningkatkan pengembangan kewirausahaan. Hasil penelitian ini mendukung pendapat Burton et al., (2011), memberikan suatu kesimpulan bahwa kinerja karyawan secara positif dan signifikan berpengaruh terhadap pengembangan kewirausahaan.

\section{SIMPULAN}


Kinerja karyawan dipengaruhi oleh kreativitas, inovasi dan motivasi. Kreativitas mempunyai pengaruh langsung yang kuat dan signifikan, oleh karena itu keberadaan kreativitas mampu menciptakan kinerja yang tinggi bagi karyawan. Inovasi mempunyai pengaruh langsung yang kuat dan signifikan terhadap kinerja karyawan, inovasi merupakan tolok ukur dalam menciptakan perubahan kegiatan pekerjaan sehari-hari, sehingga dibutuhkan inovasi yang mampu menjembadani kemauan karyawan dan kepentingan perusahaan. Motivasi juga mempunyai pengaruh yang kuat dan signifikan terhadap kinerja karyawan, artinya dibutuhkan motivasi yang tinggi untuk dapat menciptakan peningkatan kinerja karyawan, sehingga karyawan akan merasa lebih puas dan aman dalam melaksanakan tugasnya. Secara bersama-sama kreativitas, inovasi dan motivasi mempuyai pengaruh yang kuat dan signifikan tehadap kinerja karyawan.

Pengembangan kewirausahaan bagi karyawan dipengaruhi langsung oleh kreativitas, inovasi dan motivasi. Kreativitas mempunyai pengaruh langsung yang kuat dan signifikan, oleh karena itu kreativitas mampu menciptakan peningkatan kinerja karyawan. Inovasi mempunyai pengaruh langsung yang kuat dan signifikan terhadap peningkatan pengembangan kewirausahaan, inovasi merupakan dorongan dalam melaksanakan kegiatan pekerjaan sehari-hari, sehingga inovasi mampu memberdayakan karyawan sesuai dengan kondisi perusahaan. Motivasi berpengaruh langsung tetapi tidak kuat terhadap pengembangan kewirausahaan.

Kinerja karyawan mempunyai pengaruh positif terhadap pengembangan kewirausahaandan signifikan, kondisi ini menunjukkan bahwa bagi karyawan yang merasa dorongan kerjanya tinggi maka akan menciptakan kinerja yang tinggi pula, sehingga akan memaksimalkan kemampuan untuk mengembangkan jiwa kewirausahaan dalam perusahaan, semakin tinggi tingkat kinerja karyawan maka akan semakin tinggi pula tingkat pengembangan kewirausahaan.

\section{Implikasi Teoritis}

Studi ini menemukan pengaruh kreativitas, inovasi dan motivasi terhadap kinerja karyawan, dengan menemukan kreativitas, inovasi dan motivasi menuju kepada kinerja karyawan, maka akan membangun tindakan meningkatkan kepercayaan karyawan, meningkatkan kemampuan kreativitas, menambah kemampuan inovasi dan menciptakan motivasi dapat meningkatkan kinerja karyawan pada perusahaan. Tindakan berbagai pengetahuan ditunjukkan dengan kemampuan tehadap kreativitas, inovasi dan motivasi serta keinginan karyawan dalam mengembangkan kondisi perusahaan agar merasa nyaman dalam bekerja. Studi ini sejalan dengan penelitian yang telah dilakukan oleh Sihotang (2011)yang menyatakan bahwa kinerja karyawan dipengaruhi oleh kreativitas, inovasi dan motivasi.

Agar terjadi peningkatan pengembangan kewirausahaan diperlukan peningkatkan kinerja karyawan yang didasari oleh kemampuan menciptakan kreativitas, inovasi dan pemberian motivasi yang mampu melindungi karyawan 
seperti milik sendiri terhadap perusahaan. Temuan ini sejalan dengan penelitian yang dilakukan oleh Hadiyati (2011), Sihotang (2011), yang menyatakan bahwa kinerja karyawan berpengaruh positif dan signifikan terhadap pengembangan kewirausahaan.

\section{Implikasi Managerial}

Pengusaha jenang Kudus diharapkan selalu menjaga dan memelihara kondisi perusahaan melalui kreativitas, inovasi dan motivasi sebagai suatu kesatuan dalam memberikan pelayanan terhadap karyawan agar merasa nyaman dan tidak bosan dalam melaksanakan pekerjaan. Kondisi ini akan membangun sistem kepercayaan terhadap karyawan dalam sebuah organisasi.

Ketatnya persaingan usaha menyebabkan pihak perusahaan mampu menciptakan kinerja yang lebih baik antara lain dengan meningkatkan kreativitas yang maksimal, inovasi yang bisa diterima konsumen maupun karyawan, mengembangkan, serta memberikan motivasi yang bisa membawa karyawan menjadi merasa lebih nyaman.

\section{Keterbatasan Penelitian}

Hubungan antar indikator yang digunakan untuk mengukur variabel laten banyak yang memiliki nilai loading dibawah 0,5 agar model layak untuk diuji, sehingga masih dimungkinkan untuk menemukan indikator-indikator lain yang lebih sesuai untuk diteliti.

Penelitian ini hanya berdasarkan pada satu jenis industri yaitu perusahaan kecil jenang kudus di Kabupaten Kudus, sehingga masih dimungkinkan untuk dilakukan penelitian sejenis pada industri yang lain.

\section{DAFTAR PUSTAKA}

Arikunto, S.2006. Prosedur Penelitian: Suatu Pendekatan Praktik. Jakarta: Rineka Cipta.

As'ad, M. 2003.Kepemimpinan Efektif Dalam Perusahaan. Edisi 2 Yogyakarta: Liberty.

Burton, J. P.,T. W. Lee, B. C. Holtom. 2002. The influence of motivation to attend, ability to atend, and organizational commitment on different types of absence behaviours. Journal of Managerial Issues. (Summer):181-197.

Dale, A. T. 1999a. Kreativitas (Seri Manajemen Sumber Daya Manusia), penterjemah Sofyan Cikmat, Jakarta: Elex Media Komputindo. , 1999b. Memotivasi Pegawai (Seri Manajemen Sumber Daya Manusia), penterjemah Sofyan Cikmat, Jakarta: Elex Media Komputindo.

De Jong, J., danS. Wennekers. 2008.Conceptualizing entrepreneurial employee behaviour, Intrapreneurship, H200802,EIM, Netherlands. 
Donovan, R. J., danJ. R. Rossiter. 2001. Store atmosphere: An environmental psychology approach. Journal of Retailing. Vol.58 No.1: 34-57.

Djalali, M. A. 2001. Psikologi Motivasi. Minat Jabatan, Inteligensi, Bakat dan Motivasi Kerja. Malang: Wineka Media.

Ferdinand, A. 2002.Structural Equation Modeling Dalam Penelitian Manajemen.Semarang: BP UNDIP.

Frinces, H. 2004. Kewirausahaan dan Inovasi Bisnis, Cetakan Pertama, Yogyakarta: Penerbit Darusalam.

Hadiyati, E. 2010.Pemasaran untuk UMKM (Teori dan Aplikasi), Edisi Pertama, Cetakan Pertama, Malang: Bayumedia.

2011. Kreativitas dan inovasi berpengaruh terhadap kewirausahaan usaha kecil, JurnalManajemen dan Kewirausahaan. Vol.13 No.1: 8-16.

Hasibuan, M.S.P. 2005. Manajemen Sumber Daya Manusia.Edisi Revisi. Jakarta: Bumi Aksara.

Hills, G. 2008. Marketing andentrepreneur-ship, research ideas and opportunities.Journalof Small and Medium Entrepreneur-ships: 27- 39.

Kast, F.E.,danJ. E. Rosenzweig. 1995. Organisasi dan Manajemen. Terjemahan Hasyim Ali. Jakarta: Bumi Aksara.

Keh, H. T., T. T. M. Nguyen, dan H. P. Eg. 2007. The effects of entrepreneurial orientation and marketing informationon the performance of SMEs.Journal of Business Venturing: 592- 611.

Kuncoro, M. 2006. Tantangan dan Peluang Ekonomi Kerakyatan dalam Era Globalisasi Ekonomi. Analisis CSIS, XXVI, No.1.

Larsen, P.,dan A. Lewis, 2007. How award winning SMEs manage the barriers to innovation. JournalCreativity and Innovation Management: 141- 151.

Manulang, M. L. 2001. Dasar-dasar Manajemen. Jakarta: Ghalia Indonesia.

Mangkunegara, A.P.2005. Evaluasi Kinerja SDM,Bandung: Remaja Rosda Karya.

Meredith, G.G., R. E., dan Nelson, A. P. Neck. 2005. Kewirausahaan, Teori dan Praktik, Jakarta: Penerbit PPM.

Pemerintah Daerah Kabupaten Kudus. 2010. Kudus Dalam Angka.

Sedarmayanti. 2001. SDM dan Produktivitas Kerja.Bandung: Mandar Maju.

Sihotang, A. S. 2011. Analisis pengaruh kreativitas, inovasi dan motivasi pengusaha pribumi terhadap kinerja usaha daerah Jakarta, Bandung dan Medan. Tesis tidak di publikasikan.

Suharto, P. 2010. Kewirausahaan dan Manajemen Usaha Kecil, edisi 1, Yogyakarta: BPFE.

Suryana. 2003. Kewirausahaan. Pedoman Praktis, Kiat dan Proses Menunju Sukses, Edisi Revisi, Jakarta: Salemba Empat.

UU RI No.20 Tahun 2008, Tentang Usaha Mikro, Kecil dan Menengah. Jakarta: Sinar Grafika.

Wursanto, I. 2005. Dasar-Dasar Ilmu Organisasi. Yogyakarta: Andi Offset. 
Yaghoobi, N. M.,H. Salarzehi, A. Hamed,danH. Akbari. 2010. An evaluation of independent entrepreneurship obstacles in industrial SMEs.European Journal of Social Sciences: 33- 45.

Zimmerer T.W., danN. M. Scarborough. 2005. Essential of Entrepreneurship an Small Business Management, $4^{\text {th }}$, Singapore: Pearson Prentice Hall. 